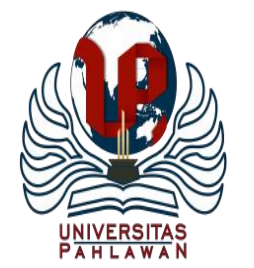

Edukatif : Jurnal Ilmu Pendidikan Volume 2 Nomor 2 Tahun 2020 Halm 202-209

EDUKATIF: JURNAL ILMU PENDIDIKAN

Research \& Learning in Education

https://edukatif.org/index.php/edukatif/index

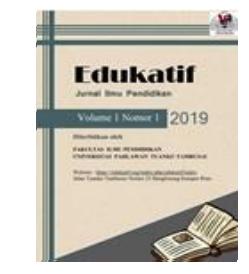

\title{
Metode Bermain Peran Dalam Meningkatkan Kemampuan Berbicara Bahasa Inggris Mahasiswa Stikes Perintis Padang
}

\author{
Nova Mustika ${ }^{1}$, Rinda Lestari ${ }^{2}$ \\ STIKes Perintis Padang ${ }^{1,2}$ \\ E-mail : nova_mustika1188@yahoo.com ${ }^{1} \underline{\text { rindalestari377@yahoo.com }}{ }^{2}$
}

\begin{abstract}
Abstrak
Penelitian ini bertujuan untuk membantu meningkatkan kemampuan mahasiswa dalam berbicara dalam Bahasa Inggris, maka peneliti menggunakan metode Role Play dengan mahasiswa mampu menggali kemampuannya dalam berbahasa Inggris, meningkatkan keinginan berbicara Bahasa Inggris dan dapat menambah kosakata Bahasa Inggris mahasiswa Analis Kesehatan STIKes Perintis Padang dalam berkomunikasi dengan Bahasa Inggris yang baik dan membangun katertarikan mahasiswa untuk belajar Bahasa Inggris, khususnya diaspek speaking. Penelitian ini merupakan penelitian tindakan kelas dengan menggunakan dua siklus yaitu, siklus I dan siklus II. Hasil penelitian menunjukan bahwa nilai rata-rata keterampilan berbicara Bahasa Inggris mahasiswa meningkat dari siklus I ke siklus ke II. Hal ini ditunjukan oleh hasil Accent pada siklus I (43,25\%) menjadi $(76,50 \%)$ pada siklus II. Penguasaan mahasiswa pada grammar siklus I (52,37\%) menjadi $(77,20 \%)$ pada siklus II. Vocabulary dari siklus I $(48,85 \%)$ menjadi $(78,40 \%)$ pada siklus II. Fluency siklus I $(63,45 \%)$ menjadi (77,65\%) pada siklus II. Comprehension meningkat dari siklus I (66,62\%) menjadi (83,50\%). Kesimpulan metode role play terbukti dapat meningkatkan keterampilan berbicara mahasiswa. Metode role play memberikan banyak kesempatan kepada mahasiswa untuk berlatih dan praktik secara langsung.
\end{abstract}

Kata kunci: metode bermain peran, kemamampuan berbicara, Bahasa Inggris

\begin{abstract}
This study aims to help improve students' ability to speak in English, so researchers use the Role Play Method with students able to explore their ability to speak English, increase the desire to speak English and can increase the vocabulary of English cities in the Health Analyst students of STIKES Perintis Padang in communicating with good English and build student interest in learning English, especially in the speaking aspect. This research is a classroom action research using two cycles namely, cycle I and cycle II. The results showed that the average value of students' English speaking skills increased from cycle I to cycle II. This is shown by the results of Accent in cycle I (43.25\%) to (76.50\%) in cycle II. Students mastery in grammar cycle I $(52.37 \%)$ to $(77.20 \%)$ in cycle II. Vocabulary from cycle I $(48.85 \%)$ to $(78.40 \%)$ in cycle II. The first cycle fluency (63.45\%) became (77.65\%) in the second cycle. Comprehension increased from cycle I (66.62\%) to (83.50\%). The conclusion of the role play method is proven to improve students' speaking skills. The role play method provides students with many opportunities to practice and practice in person.
\end{abstract}

Keywords: role playing method, speaking ability, english

Copyright (c) 2020 Nova Mustika, Rinda Lestari

$\triangle$ Corresponding author :

Address : STIKes Perintis Padang

Email : nova_mustika1188@yahoo.com

ISSN 2656-8071 (Media Cetak)

DOI: https://doi.org/10.31004/edukatif.v2i2.125

ISSN 2656-8063 (Media Online)

Edukatif : Jurnal Ilmu Pendidikan Vol 2 No 2 Tahun 2020 p-ISSN 2656-8063 e-ISSN 2656-8071 
203 Metode Bermain Peran Dalam Meningkatkan Kemampuan Berbicara Bahasa Inggris Mahasiswa Stikes Perintis Padang - Nova Mustika, Rinda Lestari

DOI: https://doi.org/10.31004/edukatif.v2i2.125

\section{PENDAHULUAN}

Manusia merupakan makhluk sosial, karena itu manusia tidak dapat hidup sendiri tanpa berinteraksi dengan orang lain. Interaksi sangat diperlukan setiap manusia, karena sebagai makhluk sosial manusia hidup saling ketergantungan dengan yang lain. Untuk berinteraksi, manusia memerlukan alat, sarana maupun media untuk menyampaikan segala keinginan, pendapat, atau perasaanya kepada orang lain. Alat, sarana maupun media tersebut adalah bahasa.

Bahasa adalah alat komunikasi yang digunakan manusia untuk berinteraksi dengan orang lain di sekelilingnya. Komunikasi yang dilakukan manusia bisa dalam kelompok kecil ataupun kelompok besar karena pada hakikatnya manusia adalah makhluk sosial yang membutuhkan hubungan dengan orang lain dan agar komunikasi yang dilakukan dapat berjalan lancar dan jelas baik secara lisan maupun tulisan manusia membutuhkan keterampilan berbahasa.

Hamid B (2014) kemampuan berkomuniasi dalam artian kemampuan berwacana yakni mampu memahami dan menghasilkan teks lisan atau tulisan yang direalisasikan dalam dua keterampilan berbahasa, yaitu keterampilan reseptif dan keterampilan produktif. Keterampilan reseptif meliputi keterampilan menyimak (listening) dan keterampilan membaca (reading), sedangkan keterampilan produktif meliputi keterampilan berbicara (speaking) dan keterampilan menulis (writing). Selanjutnya, (Djiwandono, 2008) mengatakan bahwa keterampilan berbahasa dibagi ke dalam dua kategori besar: receptive (memahami) yang terdiri dari listening dan reading dan productive (menghasilkan) yang terdiri dari speaking dan writing. Dengan penguasaan keterampilan berbahasa Inggris yang memadai, siswa tidak hanya dapat mengekspresikan ide-ide, perasaan, maupun keinginan mereka baik secara lisan maupun tertulis namun juga menggali pengetahuan yang dibutuhkan yang merupakan tuntutan kemajuan jaman.

Di antara ke-empat keterampilan berbahasa Inggris tersebut di atas, keterampilan berbicara atau speaking skill yang diajarkan di perguruan tinggi dianggap sulit bagi kebanyakan mahasiswa. Hal ini dikarenakan keterampilan berbicara memerlukan kosakata dan ungkapan-ungkapan serta pengucapan (pronunciation) yang benar dari mahasiswa dalam mengekspresikan ide-ide, pikiran, dan pengalaman mereka secara utuh dan komunikatif.

Kesulitan yang terjadi dalam belajar bahasa khususnya bahasa Inggris kebanyakan orang yang sudah memiliki pengetahuan kosakata dan tata bahasa Inggris yang baik tetapi belum mampu untuk menggunakan bahasa Inggris dalam berkomunikasi bahkan untuk percakapan seharihari. Khusus bagi mahasiswa Analis Kesehatan STIKes Perintis Padang semester 1, salah satu penyebab kurang mampunya berbahasa Inggris adalah keterbatasan ruang dan waktu untuk berlatih dan menggunakan bahasa Inggris di luar jam mata pelajaran bahasa Inggris.

Bahasa Inggris telah menjadi bahasa yang harus dikuasai oleh semua orang, bukan hanya karena statusnya sebagai bahasa dunia namun bahasa Inggris telah menjadi pendukung kehidupan untuk yang lebih baik. Bahasa Inggris 
204 Metode Bermain Peran Dalam Meningkatkan Kemampuan Berbicara Bahasa Inggris Mahasiswa Stikes Perintis Padang - Nova Mustika, Rinda Lestari DOI: https://doi.org/10.31004/edukatif.v2i2.125

mencakup semua aspek baik di bidang pendidikan maupun non pendidikan. Salah satunya adalah dibidang kesehatan, khususnya untuk analis kesehatan. Saat ini, mahasiswa program studi analis kesehatan juga harus memiliki kemampuan berkomunikasi dalam berbahasa Inggris, hal ini merupakan bahasa Ingrris sangat diperlukan dalam dunia kerja. Dengan memiliki kemampuan bahasa Inggris sebagai alat komunikasi antara pasien dan perawat menjadi berkontribusi terhadap kesuksesan dalam memberikan pelayanan apalagi kalau bekerja di rumah sakit yang berstandar Internasional.

Menurut pengamatan dan pengalaman mengajar yang dilakukan oleh peneliti dalam pembelajaran berbicara atau speaking, kesulitankesulitan tersebut juga dialami oleh mahasiswamahasiswa program studi D3 Analis Kesehatan STIKes Peritis Padang. Kesulitan mahasiswa adalah menemukan kosakata dan ungkapan yang tepat dalam bahasa Inggris untuk mengekspresikan ide-ide mereka. Kesulitan tersebut berdampak pada kurangnya kemampuan berbicara dalam bahasa Inggris. Apalagi kosakata yang berhubungan dengan dunia kesehatan terutama dalam bidang analis kesehatan.

Selain faktor tersebut di atas hal itu dilihat dari hasil skor siswa yang rata-rata sekitar 46-66 atau masuk dalam kategori Cukup (C). Selain itu, dari cara siswa mengucapkan kalimat dalam bahasa Inggris masih banyak jedaan. Dari hasil wawancara yang dilakukan, mahasiswa merasa bahasa Inggris sulit dipelajari karena saat berbicara, mahasiswa harus memiliki kosakata yang banyak, pronunciation yang tepat dan keberanian diri yang mantap ketika mencoba berbica dalam bahasa Inggris.

Permasalahan yang sama juga pernah diteliti oleh Iis Aprinawati (2017) Hal ini disebabkan oleh siswa masih merasa malu dikarenakan kurang percaya diri untuk berekspresi di depan kelas : 1) kurangnya minat maupun usaha siswa belajar berbicara dengan lafal sesuai intonasi yang tepat dalam memerankan tokoh, 2) guru kurang bervariasi dalam menggunakan metode pembelajaran karena masih menggunakan teknik dan model yang kurang tepat, 3) guru cenderung lebih banyak menggunakan model ceramah dalam pembelajaran bahasa indonesia materi drama, 4) guru masih kurang memperhatikan pelajaran keterampilan memerankan tokoh khususnya pada materi drama.

Dari permasalahan tersebut, penting untuk meningkatkan kompetensi mengajar bagi dosen. Meski begitu, dosen harus selalu berusaha keras untuk terus mencari bentuk dan model pembelajaran yang sesuai dengan mahasiswa. Penggunaan teknik dan metode pengajaran sangat penting untuk memancing dan memudahkan dosen dalam menjelaskan pembelajaran dan dalam meningkatkan pemahaman mahasiswa. Penelitian ini mencoba mencari solusi untuk mengatasi permasalahan yang dihadapi siswa dalam kegiatan belajar mengajar speaking pada mahasiswa analis kesehatan STIKes Perintis Padang. Untuk membantu meningkatkan kemampuan mahasiswa dalam berbicara dalam Bahasa Inggris, maka peneliti menggunakan metode Role Play dengan mahasiswa mampu menggali kemampuannya dalam berbahasa Inggris, meningkatkan keinginan berbicara bahasa Inggris dan dapat menambah 
205 Metode Bermain Peran Dalam Meningkatkan Kemampuan Berbicara Bahasa Inggris Mahasiswa Stikes Perintis Padang - Nova Mustika, Rinda Lestari

DOI: https://doi.org/10.31004/edukatif.v2i2.125

kosakata bahasa Inggris mahasiswa Analis Kesehatan STIKes Perintis Padang dalam berkomunikasi dengan bahasa Inggris yang baik dan membangun katertarikan mahasiswa untuk belajar bahasa inggris, khususnya diaspek speaking (Mustika, 2018).

Dengan adanya penelitian ini, peneliti berharap dapat menjadi acuan penulisan bagi penelitian kedepannya, khususnya mengenai strategi role play, selain itu peneliti dan pembaca dapat menambah pengetahuan mengenai strategi pembelajaran role play untuk mengajarkan mahasiswa terutama speaking bagi mahasiswa yang bukan berasal dari jurusan bahasa Inggris. Setelah itu, dapat meningkatkan kompetensi dosen dalam upaya memberikan pembelajaran yang efektif, atraktif dan mendemonstrasikan kepada mahasiswa STIKes Perintis Padang, khususnya mahasiswa semester I tahun akademik 2019/2020.

Lily (2019) untuk meningkatkan keterampilan berbicara salah satunya adalah dengan memberikan pemecahan masalah terhadap permasalahan yang menghambat mahasiswa. Hal ini dapat dilaksanakan antara lain dengan penggunakan metode bermain peran dalam pembelajaran Bahasa Ingris karena terbukti dapat meningkatkan keterampilan berbicara mahasiswa.

(Dananjaya, 2013) role play merupakan kegiatan dalam proses pembelajaran yang tidak boleh dikhawatirkan oleh para siswa, karena dalam kegiatan role play, situasi kehidupan nyata akan tercipta. Dalam kegiatan ini berbeda dengan drama, durasinya sangat singkat. Guru atau dosen hanya memberikan skenario singkat dan para siswa merasa bebas untuk memodifikasi atau memperbaiki situasi dan karakter. (Santoso, 2011) yang mengatakan bahwa model role playing adalah suatu cara penguasaan bahan-bahan pelajaran melalui pengembangan imajinasi dan penghayatan siswa yang di dalamnya terdapat aturan, tujuan, dan unsur senang dalam melakukan proses belajar mengajar. Richards-Amato (2003) menambahkan pula bahwa melalui kegiatan roleplaying pembelajar dapat menggali kemampuan dirinya. Menurut Harmer (2007) role-playing dapat bermanfaat untuk memacu kelancaran lisan dan melatih kemampuan pembelajar dalam kecakapan-kecakapan khusus, terutama dalam pembelajaran bahasa Inggris untuk tujuan khusus atau English for Specific Purposes. Agar simulasi terjadi peserta harus menerima tugas dan tanggung jawab peran dan fungsinya, dan lakukan yang terbaik yang mereka bisa dalam situasi di mana mereka menemu. Permainan peran sebagai proses pendidikan meliputi beberapa langkah. Pimimpin harus menguasai setiap langkah dan memberitahukannya kepada anggota kelompok. Langkah-langkah yang biasa berhubungan dengan proses permainan peran (Padang \& Lppn, 2018).

Slamet (2012) mengatakan bahwa berbicara merupakan sebuah rangkaian proses. Dalam berbicara terdapat langkah-langkah yang harus dikuasai dengan baik oleh seorang pembicara. Berikut ini merupakan langkah-langkah yang harus dikuasai oleh seorang pembicara yang baik yaitu: (a) memilih topik, minat pembicara, kemampuan berbicara, minat pendengar, kemampuan mendengar, waktu yang disediakan, (b) memahami dan menguji topik, memahami pendengar, situasi, latar belakang pendengar, tingkat kemampuan, sarana, dan (c) menyusun kerangka pembicaraan, pendahuluan, isi serta penutup. Pendapat yang 
206 Metode Bermain Peran Dalam Meningkatkan Kemampuan Berbicara Bahasa Inggris Mahasiswa Stikes Perintis Padang - Nova Mustika, Rinda Lestari

DOI: https://doi.org/10.31004/edukatif.v2i2.125

senada tentang langkah-langkah berbicara juga dikemukakan oleh Tarigan (2008) yaitu: (1) memilih pokok pembicaraan yang menarik, (2) membatasi pokok pembicaraan, mengumpulkan bahan, dan (4) menyusun bahan, yang terdiri atas: (a) pendahuluan, (b) isi, serta (c) simpulankannya sendiri.

\section{METODE PENELITIAN}

Penelitian ini merupakan penelitian tindakan kelas. Penelitian tindakan adalah suatu bentuk penelitian di mana para praktisi merefleksikan secara sistematis praktik mereka, menerapkan tindakan yang diinformasikan untuk menghasilkan perbaikan dalam praktik. Menurut Sanjaya (2008) ada empat langkah yang harus kita lakukan dalam penelitian tindakan: perencanaan, tindakan, observasi dan refleksi.

Latar penelitian dilakukan pada bulan Januari 2020 di STIkes Perintis Padang. Sampel penelitian ini adalah siswa semester satu yang sedang mengambil mata kuliah Bahasa Inggris 1 pratikum. Objek penelitian adalah semua subjek penelitian dengan sampel populasi siswa pada semester satu sebanyak 39 siswa.

Teknik pengambilan sampel menggunakan metode total sampling. Tahap pengumpulan data dilakukan sebabagi berikut:

1. Observasi atau pengamatan mengenai kegiatan yang dilakukan oleh dosen dan mahasiswa selama proses pembelajaran sesuai dengan lembar observasi yang telah disiapkan

2. Tahap pelaksanaan tindakan, analisis, refleksi terhadap setiap tindakan.
3. Diskusi antara peneliti dan mahasiswa tentang pembelajaran berbicara dengan metoda bermain peran.

4. Menganalisa dan membahas perubahan kemampuan berbicara mahasiswa dengan tes akhir yaitu tes kinerja (tes praktik).

Penilaian yang digunakan dalam penelitian ini mengacu pendapat Rahmawati (2016) dalam menilai kemampuan berbicara seseorang sekurangkurangnya ada lima hal yang harus diperhatikan yaitu: (1) Accent, (2) Grammar, (3) Vocabulary, (4) Fluency, dan (5) Comprehension.

Analisis data dalam penelitian tindakan kelas ini berupa deskriptif kualitatif dan deskriptif kuantitatif. Analisis deskriptif kualitatif dalam penelitian ini bersifat menggambarkan fakta sesuai data yang diperoleh dari lembar observasi terhadap kegiatan mahasiswa dan dosen selama proses pembelajaran. Data yang diperoleh dari lembar observasi terdiri atas dua macam. Data tersebut meliputi data pengamatan terhadap pembelajaran keterampilan berbicara yang dilakukan dosen dan data pengamatan terhadap mahasiswa dalam kegiatan diskusi dan mengevaluasi peran yang ditampilkan oleh mahasiswa.

Data kuantitatif diperoleh dari hasil tes praktik mahasiswa dalam role play. Tes praktik dilakukan untuk mengukur keterampilan berbicara bahasa Inggris mahasiswa dengan metode role play. Hasil tes ini dianalisis secara kuantitatif untuk mengetahui ada tidaknya peningkatan keterampilan berbicara mahasiswa yang dilakukan dengan membandingkan hasil tes di akhir setiap siklus. Analisis deskriptif kuantitatif dilakukan dengan melakukan perhitungan rerata (mean) hasil 
207 Metode Bermain Peran Dalam Meningkatkan Kemampuan Berbicara Bahasa Inggris Mahasiswa Stikes Perintis Padang - Nova Mustika, Rinda Lestari

DOI: https://doi.org/10.31004/edukatif.v2i2.125

tes mahasiswa ketika tindakan dilakukan. Jika persentase $\geq 75 \%$ dan mengalami kenaikan setiap siklusnya, maka diasumsikan bahwa metode bermain peran dapat meningkatkan keterampilan berbicara bahasa Inggris mahasiswa. Hasil refleksi dari siklus I menjadi dasar untuk melaksanakan siklus II, dan begitu seterusnya.

\section{HASIL DAN PEMBAHASAN PENELITIAN}

Menurut hasil pengamatan dan kegiatan bermain peran yang dihasilkan mahasiswa, metode ini terbukti membantu mahasiswa untuk lebih aktif dalam proses pratikum Bahasa Inggris terutama pada kompetensi speaking, serta meningkatkan kemampuan berbicara mahasiswa khususnya dalam menggali ide-ide tentang kosakata yang akan dipakai dalam suatu pembiacaraan (conversation) dan menambah kosakata mahasiswa yang berkaitan dengan Analis Kesehatan.

Pada pertemuan kedua siklus I, peneliti memberi lebih banyak kesempatan kepada mahasiswa untuk mendiskusikan topik tersebut untuk meningkatkan keterampilan mereka dalam speaking. Dari tes speaking mereka belum terlalu meningkat. Pada pertemuan ketiga di siklus I, peneliti masih mencoba untuk memperbaiki pemahaman mereka tentang topik dan keterampilan mereka dalam berbicara, karena hasil tes speaking mereka masih rendah. Pada tabel dibawah ini dapat dilihat nilai rata- rata speaking mahasiswa pada siklus I.
Tabel 1. Nilai rata-rata speaking mahasiswa pada siklus I

\begin{tabular}{ccc}
\hline No & Indicator & Persentase \\
\hline 1 & Accent & $43,25 \%$ \\
\hline 2 & Grammar & $52,37 \%$ \\
\hline 3 & Vocabulary & $48,85 \%$ \\
\hline 4 & Fluency & $63,45 \%$ \\
\hline 5 & Comprehension & $66,62 \%$ \\
\hline
\end{tabular}

Berdasarkan tabel, kemampuan nilai ratarata speaking mahasiswa. Berikut adalah diagram nilai rata-rata kemampuan speaking mahasiswa.

Dalam siklus ini, peneliti membuat perencanaan yang lebih baik dari sebelumnya. Pada pertemuan pertama di siklus II, peneliti meminta siswa untuk mendengar pengucapan guru tentang materi sehingga dapat meningkatkan aksen mereka dalam presentasi mereka. Pada pertemuan kedua di siklus II, peneliti fokus pada kelancaran mereka dalam kemampuan speaking. Di sini, peneliti meminta siswa berlatih keras dalam diskusi kelompok mereka bahkan di rumah mereka. Pada pertemuan terakhir pada siklus kedua, peneliti dapat menemukan peningkatan kemampuan speaking siswa berdasarkan masingmasing indikator dengan menggunakan strategi role play. Peningkatan nilai siswa dapat dilihat pada tabel berikut.

Tabel 2. Nilai rata-rata speaking mahasiswa pada siklus II

\begin{tabular}{ccc}
\hline No & Indicator & Persentase \\
\hline 1 & Accent & $76,50 \%$ \\
\hline 2 & Grammar & $77,20 \%$ \\
\hline 3 & Vocabulary & $78,40 \%$ \\
\hline 4 & Fluency & $77,65 \%$ \\
\hline 5 & Comprehension & $83,50 \%$ \\
\hline
\end{tabular}


208 Metode Bermain Peran Dalam Meningkatkan Kemampuan Berbicara Bahasa Inggris Mahasiswa Stikes Perintis Padang - Nova Mustika, Rinda Lestari

DOI: https://doi.org/10.31004/edukatif.v2i2.125

Bedasarkan tabel di atas, menunjukkan peningkatan nilai speaking siswa. Adapun perbandinagan peningkatan nilai rata-rata speaking siswa dari siklus I dan siklus II dapat dilihat pada tabel dibawah ini.

Tabel 3. Nilai rata-rata speaking mahasiswa pada siklus I dan II

\begin{tabular}{cccc}
\hline No & Indicator & $\begin{array}{c}\text { Persentase } \\
\text { Siklus I }\end{array}$ & $\begin{array}{c}\text { Persentase } \\
\text { Siklus II }\end{array}$ \\
\hline 1 & Accent & $43,25 \%$ & $76,50 \%$ \\
\hline 2 & Grammar & $52,37 \%$ & $77,20 \%$ \\
\hline 3 & Vocabulary & $48,85 \%$ & $78,40 \%$ \\
\hline 4 & Fluency & $63,45 \%$ & $77,65 \%$ \\
\hline 5 & Comprehension & $66,62 \%$ & $83,50 \%$ \\
\hline
\end{tabular}

Dari tabel dan diagram diatas dapat dilihat peningkatan skill speaking siswa sesuai dengan indikatornya. Hal itu menunjukkan bahwa Accent mereka menjadi lebih baik dari rata-rata tes speaking pada siklus I $(43,25 \%)$ sampai II $(76,50 \%)$ pada rata-rata tes speaking pada siklus II. Dapat dibaca bahwa penguasaan siswa pada grammar lebih baik dalam tes speaking pada siklus I $(52,37 \%)$ sampai $(77,20 \%)$. Berdasarkan data di atas terjadi peningkatan penguasaan siswa terhadap vocabulary dari siklus I $(48,85 \%)$ menjadi siklus II (78,40\%). Fluency mereka dalam mengucapkan kata-kata dan kalimat menjadi lebih baik dari pada siklus I $(63,45 \%)$ menjadi (77,65\%). Comprehension mahasiswa meningkat dari siklus I $(66,62 \%)$ menjadi $(83,50 \%)$.

Dari hasil penelitian ini pembelajaran Bahasa Inggris dengan menggunakan metode role play dapat meningkatkan kemampuan berbahasa Inggris mahasiswa hal ini terlihat dari persentase hasil yang diperoleh mahasiswa meningkat dari siklus I ke siklus II. Berdasarkan peningkatan persentase di atas diketahui bahwa penggunaan metode role play dapat meningkatkan keterampilan berbicara mahasiswa dalam pembelajaran Walaupun dalam Pembelajaran siklus II masih ditemukan 4 orang mahasiswa yang belum mencapai KKM.

\section{KESIMPULAN}

Kesimpulan belajar Bahasa Inggris adalah pembelajaran yang sulit bagi mahasiswa, karena mahasiswa masih banyak yang kurang berani berbicara dengan Bahasa Inggris serta mahasiswa juga tidak memiliki kosakata yang banyak dalam Bahasa Inggris. Setelah melakukan penelitian dengan metode role play, terlihat peningkatan skor berbicara mahasiswa dan meningkatkan keterampilan berbahasa Inggris mahasiswa dan menambah kosakata dalam bahasa Inggris.

Hasil penelitian menunjukkan hasil yang diperoleh mahasiswa meningkat dari siklus I ke siklus II. Merujuk kepada hasil penelitian, maka saran-saran yang peneliti berikan adalah bahwa proses pembelajaran mata kuliah Bahasa Inggris khususnya dalam aspek keterampilan berbicara pada mahasiswa program studi Analis Kesehatan pada mata kuliah Pratikum Bahasa Inggris 1 sebaiknya diterapkan dalam pembelajaran yang menarik yang dapat memotivasi mahasiswa untuk aktif. Bahasa Inggris special Analis Kesehatan bertujuan untuk mengembangkan pengetahuan, keterampilan berbahasa dan sikap positif terhadap penggunaan bahasa Inggris untuk berinteraksi dalam dunia kesehatan menggunakan Bahasa Inggris. Oleh karena itu, metode role play terbukti dapat meningkatkan keterampilan berbicara 
209 Metode Bermain Peran Dalam Meningkatkan Kemampuan Berbicara Bahasa Inggris Mahasiswa Stikes Perintis Padang - Nova Mustika, Rinda Lestari

DOI: https://doi.org/10.31004/edukatif.v2i2.125

mahasiswa. Metode role play memberikan banyak kesempatan kepada mahasiswa untuk berlatih dan praktik secara langsung.

\section{DAFTAR PUSTAKA}

Dananjaya, U. (2013). Media Pembelajaran Aktif. Nuansa.

Djiwandono, M. S. (2008). Tes Bahasa Dalam Pengajaran. Itb Bandung.

Hamid B, L. O. M. I. (2014). Peningkatan Kemampuan Berbicara Bahasa Inggris Melalui Media Gambar Berseri. Bahtera: Jurnal Pendidikan Bahasa Dan Sastra, 13(1), $\quad$ 88-95. Https://Doi.Org/10.21009/Bahtera.131.09

Harmer, J. (2007). The Practice Of English Language Teaching (4th Ed). Pearson Longman.

Iis Aprinawati. (2017). Peningkatan Keterampilan Memerankan Tokoh Dengan Menggunakan Metode Sosiodrama Siswa Kelas V Sd Negeri 024 Kota Pekanbaru. Jurnal Basicedu, 1(2), 43.

Lily. (2019). Peningkatan Kemampuan Berbicara Bahasa Inggris Melalui Metoda Bermain Peran Di Akper Malahayati Medan. Wahana Inovasi, 8(2), 104.

Mustika, N. (2018). Penggunaan Strategy Role Play Untuk Meningkatkan Skill Dan. 1(1).

Padang, U. N., \& Lppn, S. (2018). Pada Mata Kuliah Sosiologi. 2(114).

Rahmawati, Y. (2016). Developing Assessment For Speaking.

Richards-Amato, P. (2003). Making It Happen: From Interactive To Participatory Language Teaching. Pearson Education, Inc.

Sanjaya, W. (2008). Strategi Pembelajaran Berorientasi Standar Proses Pendidikan. Kencana Prenada Media.

Santoso, R. B. E. (2011). Model Pembelajaran Role Playing.
Slamet, S. Dan. (2012). Saddhono Dan Slamet. Saddhono Dan Slamet.

Tarigan, H. . (2008). Pengajaran Kompetensi Bahasa. Angkasa. 